\title{
Transformations of Regional Economic Governance in the Gulf Cooperation Council
}

Fred Lawson

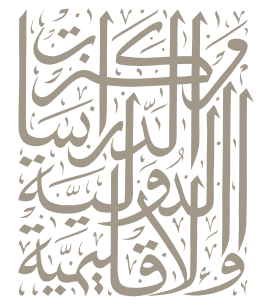

\section{CIRS}

CENTER FOR INTERNATIONAL AND REGIONAL STUDIES

GEORGETOWN UNIVERSITY SCHOOL OF FOREIGN SERVICE IN QATAR 


\section{Transformations of Regional Economic Governance in the Gulf Cooperation Council}

Fred H. Lawson

(C) 2012 Center for International and Regional Studies

Georgetown University School of Foreign Service in Qatar

Occasional Paper No. 10

ISSN 2072-5957 


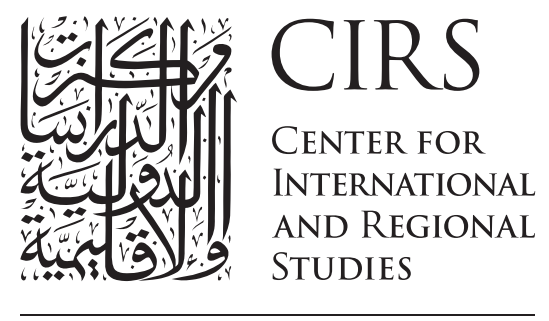

GEORGETOWN UNIVERSITY

SCHOOL OF FOREIGN SERVICE IN QATAR

Established in 2005, the Center for International and Regional Studies at the Georgetown University School of Foreign Service in Qatar is a premier research institute devoted to the academic study of regional and international issues through dialogue and exchange of ideas, research and scholarship, and engagement with national and international scholars, opinion makers, practitioners, and activists.

Guided by the principles of academic excellence, forward vision, and community engagement, the Center's mission revolves around five principal goals:

- To provide a forum for scholarship and research on international and regional affairs

- To encourage in-depth examination and exchange of ideas

- To foster thoughtful dialogue among students, scholars, and practitioners of international affairs

- To facilitate the free flow of ideas and knowledge through publishing the products of its research, sponsoring conferences and seminars, and holding workshops

designed to explore the complexities of the twenty-first century

- To engage in outreach activities with a wide range of local, regional, and international partners.

This publication series is made possible by the generous support of Qatar Foundation for Education, Science and Community Development. 


\section{Transformations of Regional Economic Governance in the Gulf Cooperation Council}

Fred H. Lawson

Fred H. Lawson is Lynn T. White, Jr. Professor of Government at Mills College in Oakland, California. He is author of Constructing International Relations in the Arab World (2006), and editor of Comparative Regionalism (2009) and Demystifying Syria (2009). In 2009-2010, Lawson was Senior Fellow at CIRS. He is past president of both the Society for Gulf Arab Studies and the Syrian Studies Association. 


\begin{abstract}
Most studies of regionalism in the Middle East fail to distinguish among divergent types of regional formations, and make little effort to chart the developmental trajectory that regionalist projects display over time. This paper lays out a typology that can be used to elucidate crucial differences across regional formations in the contemporary Arab world, and also to highlight significant changes in the kind and level of governance that take place in any particular regionalist experiment. The utility of the framework is demonstrated through an analysis of the Gulf Cooperation Council (GCC). This regional formation has undergone two major transformations since it took shape in 1981, and at the present time exhibits a substantially different form of economic regionalism from the one it boasted three decades ago. Four alternative explanations for shifts from one form of GCC regionalism to another are outlined as an invitation to further investigation.
\end{abstract}

\title{
Introduction
}

Surveys of economic integration in the Middle East and North Africa usually include a list of regional organizations and institutions that have been set up to promote sustained growth and market efficiency in this part of the world. Among these can be found the League of Arab States (Arab League), the Arab Maghreb Union (AMU), the Arab Cooperation Council (ACC), the Cooperation Council of the Arab States of the Gulf (Gulf Cooperation Council or GCC), the Greater Arab Free Trade Area (GAFTA), and the Mediterranean Free Trade Area (MFTA). Only a few of these regionalist projects have been analyzed in any detail, whether in the literature on regional integration in the Arab world or in broader studies of comparative regionalism. More importantly, existing scholarship on economic regionalism in the Middle East and North Africa tends to ignore crucial variations in the institutional structures, policy-making procedures, and developmental trajectories that can be seen in different cases. Consequently, hypotheses concerning the emergence, consolidation, and impact of regionalist projects that are advanced in writings about this part of the globe tend to be fundamentally misconceived. 
Such misconceptions are likely to get perpetuated and compounded as scholars of regionalism set out to explore the dynamics of regional economic governance. ${ }^{1}$ Locating the primary sites of economic regulation, identifying the key actors involved in managing commercial and financial transactions among countries, and disentangling the complex interplay between formal and informal institutions at the supranational and national levels will require careful attention to subtle differences across such superficially similar-but inherently disparate-entities as the AMU, ACC, and GCC. Moreover, each one of these regional formations has undergone profound transformations over time, making generalizations about the origins, evolution, and consequences of regional economic governance with respect to any one of them even more problematic.

\section{Types of Regionalist Projects}

Regionalist economic projects in the contemporary world can best be categorized along four analytically distinct dimensions: a) the degree to which supranational (or multilateral) institutions have the authority to formulate and implement policy independently of the actions and interests of individual member-states; b) what kind of rules and procedures govern decision-making in regional economic organizations; c) the extent to which regional organizations provide incentives that can induce member-states to comply with programs that promote the interests of the region as a whole; and d) the amount of effort that regional organizations devote to augmenting the level of interdependence among member-states. ${ }^{2}$

Operationalizing these concepts is no easy task. There is almost certainly a major difference between regionalist projects whose institutions can adopt and implement policies that regulate a significant number of economic issues and ones in which regional institutions exercise authority over no important matters. Given the

\footnotetext{
${ }^{1}$ Edward Best, "The Assessment of Regional Governance: Principles, Indicators and Potential Pitfalls," UNUCRIS Working Paper 2008/10 (Bruges: Comparative Regional Integration Studies, United Nations University, 2008); Miles Kahler and David A. Lake, "Economic Integration and Global Governance: Why So Little Supranationalism?" in The Politics of Global Regulation, eds., Walter Mattli and Ngaire Woods (Princeton: Princeton University Press, 2009); Helen E. S. Nesadurai, "ASEAN and Regional Governance after the Cold War," The Pacific Review 22, no. 1 (March 2009); Hidetaka Yoshimatsu, "Regional Cooperation in Northeast Asia: Searching for the Mode of Governance," International Relations of the Asia-Pacific 10, no. 2 (May 2010); Rosemary Foot, "The Role of East Asian Regional Organizations in Regional Governance: Constraints and Contributions," Carnegie Endowment for International Peace, June 7, 2011, http://carnegieendowment.org/2011/06/07/role-ofeast-asian-regional-organizations-in-regional-governance-constraints-and-contributions $/ 1 \mathrm{kqn}$; Lorraine Elliott and Shaun Breslin, eds., Comparative Environmental Regionalism (Abingdon: Routledge, 2011). See also Kristian Coates Ulrichsen, “The GCC States and the Shifting Balance of Global Power," CIRS Occasional Paper 6 (Doha: Center for International and Regional Studies, Georgetown University School of Foreign Service in Qatar, 2010); Kristian Coates Ulrichsen, "Rebalancing Global Governance: Gulf States' Perspectives on the Governance of Globalisation,” Global Policy 2, no. 1 (January 2011).

${ }^{2}$ Fred H. Lawson, "Comparing Regionalist Projects in the Middle East and Elsewhere: One Step Back, Two Steps Forward," in Beyond Regionalism? Regional Cooperation, Regionalism and Regionalization in the Middle East, eds., Cilja Harders and Matteo Legrenzi (Aldershot: Ashgate, 2008).
} 
wide variety of specific issues that have been identified in the literature on regional integration, ${ }^{3}$ however, defining "a significant number" in the way that this literature does-as more than half of the issues at hand-seems excessive. In fact, ceding control over as few as two important matters to supranational institutions would be a remarkable act on the part of self-interested, sovereign states, each one jealous of its prerogatives and deeply mistrustful of the intentions of others. It therefore appears reasonable to recognize three analytically distinct types of regionalist projects: 1) those in which regional institutions exercise authority over no major economic issues; 2) those in which regional institutions exercise authority over one or two major issues; and 3) those in which regional institutions exercise authority over three or more major issues.

How decisions get made in multilateral institutions also distinguishes different regionalist projects from one another. Regional organizations in which programs can only be undertaken if each and every member-state explicitly gives its approval have little in common with ones that can adopt and implement policies even if not all member-states vote to do so. It thus makes sense to code decision-rules according to whether policy-making in regional institutions operates on the basis of i) unanimous consent, ii) some arrangement whereby a subset of member-states exercises a veto, or iii) majority rule, whether simple or weighted. It is important to remember that characterizing decision-making procedures according to formal agreements and stated procedures may well blind us to how such agencies actually work. In the case of the Gulf Cooperation Council, for example, it is hard to imagine that any important initiative could be carried out without the approval or acquiescence of Saudi Arabia. Determining whether or not specific member-states enjoy de facto veto power is more likely to involve informed judgments than ironclad stipulations.

Incentives that can convince member-states to comply with regional directives come in a variety of forms. The most obvious entail positive or negative sanctions, that is, rewards to individual governments if they act in accordance with regional interests, and punishments if they behave in self-interested or exploitative ways. Some (but not many) multilateral institutions command substantial pools of resources, which enable them to confer or withhold sanctions at their own discretion; others possess no resources of their own, and rely on member-states to mete out rewards and punishments. Between the two extremes stand regionalist projects that include free trade arrangements, which generate market efficiencies that make it highly (and increasingly) unattractive for member-states to defect from the collective interest.

\footnotetext{
${ }^{3}$ Joseph Nye, "Comparative Regional Integration: Concept and Measurement," International Organization 22, no. 4 (Autumn 1968); Leon Lindberg, "Political Integration as a Multi-Dimensional Phenomenon Requiring Multivariate Measurement," International Organization 24, no. 4 (Autumn 1970).
} 
Finally, regionalist economic projects differ with regard to how dependent member-states are on one another. Even though existing studies measure levels of regionalism in terms of the proportion of trade and investment that members carry out among themselves, it is much more instructive to categorize regionalist projects according to how costly it would be if intra-regional trade and investment abruptly vanished. This definition corresponds to the notion of interdependence that is held by most students of world politics, not to mention common sense. ${ }^{4}$ Whether or not multilateral institutions are taking steps to promote regional interdependence might be inferred from official pronouncements, although public statements of intent must always be treated with a good deal of caution. More perplexing is the question of whether heightened interdependence can best be measured in terms of explicit, overt programs that are designed to forge commercial and financial connections whose disruption would prove costly to all of the states involved, or instead in terms of the emergence of such relations of mutual reliance, whether or not they are actually intended.

These four attributes offer a promising typology that can be used to spell out 54 theoretically distinct types of regionalist projects (Figure 1). An even more precise way to distinguish divergent forms of regionalism would be to conceive of each one of these structural features as a continuum, along which particular cases can be situated relative to one another. But, since four-dimensional space is almost impossible to depict on a one-dimensional surface, and seems to be just about as hard to visualize mentally, the matrix presented here represents a plausible startingpoint for comparative investigation.

\section{Economic Regionalism and the GCC}

Situating any specific instance of economic regionalism in terms of the framework presented in Figure 1 is a tricky analytical exercise. Even more difficult is the task of explaining why regionalist projects at times shift from one cell of the matrix to another. To illustrate the utility of the typology, I propose to deploy it here to chart the developmental trajectory of regional economic governance in the Gulf Cooperation Council. ${ }^{5}$ This analytical exercise will be followed by a few provisional comments about how successive transformations in the type of regionalism seen in the GCC over the past three decades might best be explained.

\footnotetext{
${ }^{4}$ David A. Baldwin, "Interdependence and Power: A Conceptual Analysis," International Organization 34, no. 4 (Autumn 1980).

${ }_{5}$ This paper builds on Fred H. Lawson, "Theories of Integration in a New Context: The Gulf Cooperation Council," in Racing to Regionalize, eds., Kenneth P. Thomas and Mary Ann Tétreault (Boulder, Colo.: Lynne Rienner, 1999).
} 

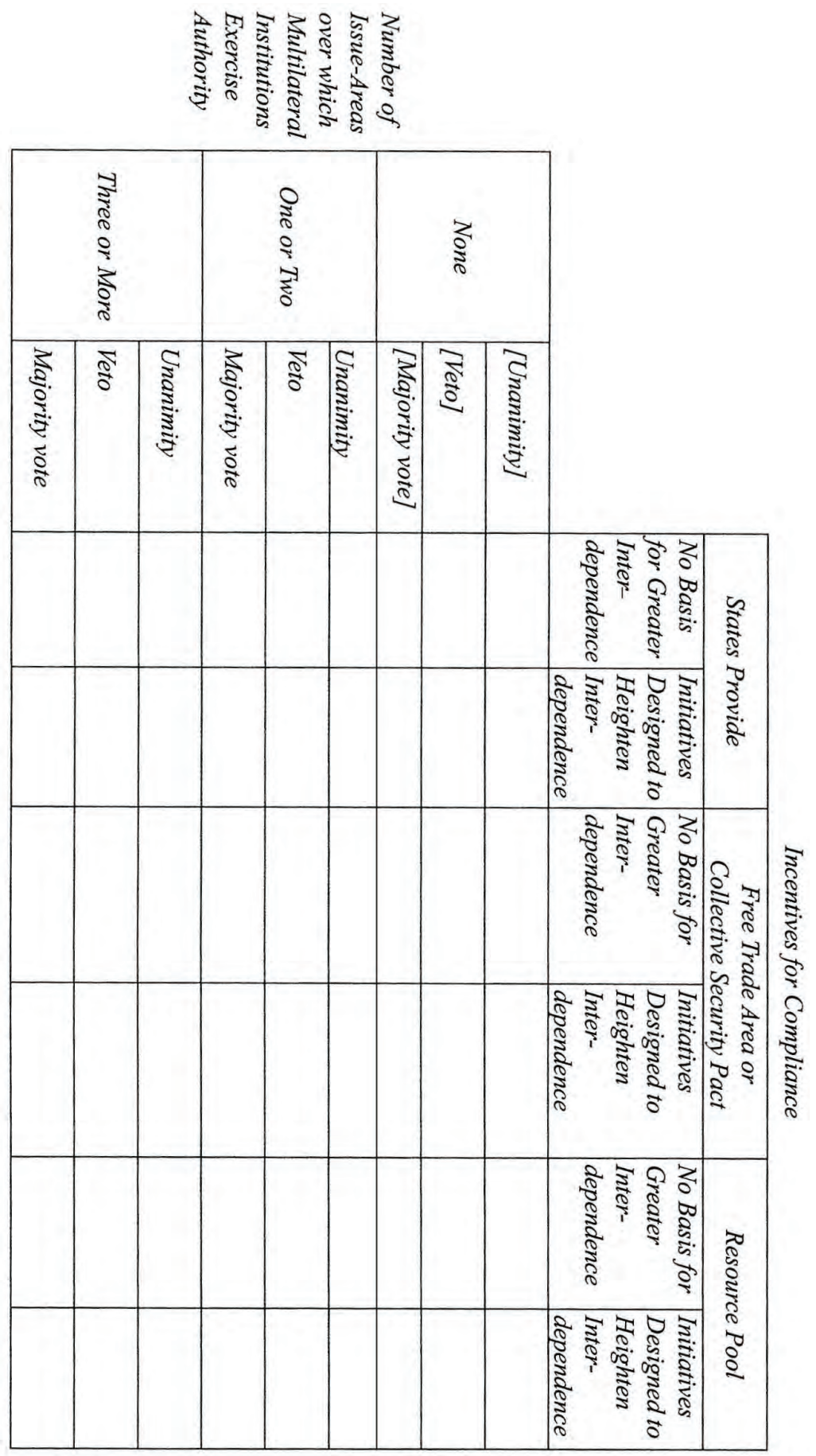

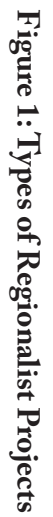




\section{Early Initiatives}

Despite the appearance of a handful of supranational agencies and institutions, economic regionalism among the six Gulf Cooperation Council states-Kuwait, Saudi Arabia, Bahrain, Qatar, the United Arab Emirates (UAE), and Omanremained no more than minimal throughout the 1970s. ${ }^{6}$ Only in the wake of Iraq's September 1980 military assault on the Islamic Republic of Iran did regionalist initiatives start to blossom.

In February 1981, the six foreign ministers met in Riyadh and appointed a Committee of Experts to work out the precise steps whereby greater economic integration might be fostered. The committee began work later that month, basing its deliberations on competing proposals. The first, advanced by Kuwait with the backing of Saudi Arabia, envisaged the immediate implementation of a wide range of measures to promote economic unity; and the second, submitted by Oman, accorded higher priority to military cooperation, particularly joint efforts to protect sea lanes in the Gulf. Even after the Committee of Experts opted for the Kuwaiti proposal, a Saudi-sponsored "national security council" for the Gulf took charge of coordinating the activities of the six countries' internal security services. ${ }^{7}$ On May 24, 1981, the foreign ministers of the prospective member-states met in Abu Dhabi and nominated an experienced Kuwaiti diplomat, 'Abdullah Y. Bishara, to be secretary general of the new GCC. The next day, the rulers of the six countries arrived in Abu Dhabi to sign the GCC Charter. ${ }^{8}$

Immediately after constituting themselves as the Supreme Council of the GCC, the rulers of the six member-states promulgated a Unified Economic Agreement (UEA). This document pledged the signatories to establish a uniform system of tariffs; to practice nondiscrimination among GCC members with regard to regulations governing the flow of capital and labor across their common borders; to "coordinate their policies with regard to all aspects of the oil industry;" to harmonize their respective industrial development programs; and to take steps

\footnotetext{
${ }^{6}$ Roger Nye, "Political and Economic Integration in the Arab States of the Gulf," Journal of South Asian and Middle Eastern Studies 2, no. 1 (Fall 1978); Fouad Hamdi Beseisu, "Sub-Regional Economic Cooperation in the Arab Gulf," Arab Gulf Journal 1, no. 1 (October 1981); Frauke Heard-Bey, Die Arabischen Golfstaaten im Zeichen der Islamischen Revolution (Bonn: Europa Verlag, 1983); Matteo Legrenzi, The GCC and the International Relations of the Gulf (London: I. B. Tauris, 2011), 20-25; Alexis Antoniades, "The Gulf Cooperation Council Monetary Union," in The Political Economy of the Persian Gulf, ed. Mehran Kamrava (New York/London: Columbia University Press/Hurst, 2012), 176.

${ }^{7}$ John Christie, "History and Development of the Gulf Cooperation Council," American-Arab Affairs 18 (Fall 1986): 4; Anthony H. Cordesman, The Gulf and the Search for Strategic Stability (Boulder, Colo.: Westview Press 1984), 627.

8 "Charter," American-Arab Affairs 7 (Winter 1983-1984).

9 “The Unified Economic Agreement," American-Arab Affairs 7 (Winter 1983-1984).
} 
"to unify investment in order to achieve a common investment policy." 10 The rapid adoption of the UEA convinced some outside observers that economic rather than security considerations lay behind the formation of the GCC. ${ }^{11}$ This impression was reinforced by the July 1981 appointment of an activist secretary general to oversee the Arab Gulf Organization for Industrial Consultancy (AGOIC). The new AGOIC head quickly authorized construction of a regional tire factory in Kuwait and an aluminum rolling mill in Bahrain, among several other collaborative ventures. GCC industry ministers met in October 1981 to discuss ways to coordinate future manufacturing projects. ${ }^{12}$ Furthermore, in November 1982, the member-states set up a Gulf Investment Corporation to provide financial support for complementary strategies that might diversify the regional economy. ${ }^{13}$

It therefore seems evident that the GCC at its inception should be placed in the fourth column of Figure 1: the initial agenda of this particular regionalist project contained a handful of measures intended to heighten the level of interdependence among the six member-states, and the UEA called for the establishment of a free trade area that offered incentives for greater inter-state collaboration. It seems equally clear that the GCC also belongs in the fourth row of the matrix. The organization's secretariat was accorded considerable leeway to set standards and measures for common use among the member-states, ${ }^{14}$ while unanimity was mandated in order for policies to be adopted and carried out, whether in the Supreme Council of rulers or the Ministerial Council of foreign ministers.

\section{Early Regression}

After an initial burst of regionalist activism, economic integration among the GCC states sputtered and then stalled. During the organization's first five years in existence, virtually no effort was made to unify the member-states' disparate monetary systems. ${ }^{15}$ With respect to commercial affairs, in May 1983, the Ministerial Council recommended the adoption of a common external tariff. By the fall of that year, Kuwait and Bahrain had brought their customs regulations into conformity with

\footnotetext{
${ }^{10}$ Ibid.

${ }^{11}$ David Priess, "Balance-of-Threat Theory and the Genesis of the Gulf Cooperation Council," Security Studies 5, no. 4 (Summer 1996): 150.

${ }^{12}$ Legrenzi, GCC and the International Relations, 68.

${ }^{13}$ Khaled Al-Fayez, “The Gulf Investment Corporation," American-Arab Affairs 11 (Winter 1984-1985); Legrenzi, GCC and the International Relations, 67.

${ }^{14}$ Michael Barnett and F. Gregory Gause III, "Caravans in Opposite Directions: Society, States and the Development of Community in the Gulf Cooperation Council," in Security Communities, eds., Emanuel Adler and Michael Barnett (Cambridge: Cambridge University Press, 1998), 176.

${ }^{15}$ Theodore Hitiris and Michael H. Hoyle, "Monetary Integration in the GCC: An Evaluation," Arab GulfJournal 6, no. 1 (October 1986); Iqbal Zaidi, "Monetary Coordination among the Gulf Cooperation Council Countries," World Development 18, no. 5 (May 1990).
} 
the proposed system, but Saudi Arabia, Qatar, and Oman pleaded for more time to reconfigure their respective customs administrations, while the UAE expressed outright opposition to the revised tariff structure. ${ }^{16}$

Furthermore, the winding down of the Iran-Iraq war accompanied a resurgence of trade barriers throughout the Gulf. In early 1988, Saudi Arabia raised customs duties from $7 \%$ to $12 \%$ ad valorum on most imports, while increasing tariffs from $10 \%$ to $20 \%$ on re-exports coming into the kingdom through Port Rashid in the UAE.$^{17}$ Bahrain, meanwhile, adopted new regulations that authorized state agencies to discriminate in favor of domestic products, so long as the price differential between locally-produced items and equivalent imports remained less than $10 \% .{ }^{18}$ Even when the six ministers of industry proposed in June 1989 to regularize tariffs among member-states, the proposal ended up being rejected by the six finance ministers, who recommended that different products continue to be treated in different ways. ${ }^{19}$ The Supreme Council endorsed the finance ministers' recommendation, further delaying the implementation of a unified customs regime. ${ }^{20}$

Meanwhile, slumping prices on world oil markets, combined with wartime disruptions in trade and finance, created unprecedented economic difficulties in all six member-states. Each government responded to the crisis in a substantially different fashion. ${ }^{21}$ Oil-rich countries pursued sharply divergent strategies inside the Organization of Petroleum Exporting Countries (OPEC) from the ones that were adopted by less well-endowed members. ${ }^{22}$ Moreover, the August 1982 collapse of Kuwait's unofficial stock market, the Suq al-Manakh, sent a chill through regional financial circles. The ensuing turmoil prompted the central banks of each of the GCC states to adopt new regulations to govern lending and bookkeeping practices by the financial institutions that operated inside their respective borders. These regulations tightly restricted the flow of monetary reserves and investment capital from one member-state to another. ${ }^{23}$

Industrial integration proved no more ineluctible than commercial or financial integration. In the fall of 1984, the AGOIC published a major report on trends in the Gulf cement industry. The report advised GCC member-states to collaborate

\footnotetext{
${ }^{16}$ Middle East Economic Digest (MEED), September 9, 1983.

${ }^{17}$ MEED, February 13, 1988.

${ }^{18}$ MEED, January 16, 1988.

${ }^{19} M E E D$, June 2, 9, and 16, 1989.

${ }^{20}$ MEED, January 12, 1990, and February 23, 1990.

${ }^{21}$ Shireen T. Hunter, "The Gulf Economic Crisis and its Social and Political Consequences," Middle East Journal 40, no. 4 (Autumn 1986); Fred H. Lawson, "Managing Economic Crises: The Role of the State in Bahrain and Kuwait," Studies in Comparative International Development 26, no. 1 (Spring 1991).

${ }^{22}$ MEED, October 28, 1983.

${ }^{23}$ Henry T. Azzam, The Gulf Economies in Transition (New York: St. Martin's, 1988), 97.
} 
in the production and distribution of cement in order to reduce unit costs and to preclude the emergence of surplus capacity in the region. In particular, it urged the UAE "to stop issuing licenses for new [cement] works, and instead concentrate on co-ordinating clinkers supply and grinding capacity [with other countries], ${ }^{24}$ while calling on the Kuwait Cement Company to postpone plans to enlarge its existing plant. Neither government followed the AGOIC's recommendations. Instead, each of the GCC states took steps to expand its own cement industry, "looking for salvation to an early end to the war between Iraq and Iran, and a surge in cement demand to supply reconstruction work in both countries. ${ }^{25}$ In a similar fashion, as demand for aluminum surged in regional markets, Qatar, Saudi Arabia, and Umm al-Qaiwain in the UAE all announced plans to construct large-scale smelters, which would compete not only with one another, but also with existing aluminum plants in Bahrain and Dubai. ${ }^{26}$ Conversely, whereas the AGOIC strongly recommended that the GCC take steps to augment regional iron and steel production, the UAE authorities shut down recently opened rolling mills in Abu Dhabi, Dubai, and Ras al-Khaimah as soon as they showed signs of operating at a loss. ${ }^{27}$

\section{Renewed Regionalism}

An evanescent spurt of regionalism among the six member-states occurred in the aftermath of the Second Gulf War. As soon as the fighting ended in March 1991, GCC finance ministers authorized the creation of a US $\$ 10$ billion fund to support Arab and Islamic countries whose economies had been damaged as a result of the conflict. Responsibility for managing the fund was placed in the hands of a special commission composed of directors of existing Gulf development agencies. The commission's activities were coordinated with the operations of the World Bank and International Monetary Fund, and preference was accorded to private sector projects. ${ }^{28}$ Towards the end of November 1991, GCC trade ministers met in Qatar to discuss ways to accelerate the formation of a regional customs union; in midDecember, the governors of the six central banks announced that they intended to issue a single currency by the year 1999. ${ }^{29}$ Prospects for a unified currency brightened when Kuwait decided to join the other GCC states in pegging the value of the Kuwaiti dinar to that of the US dollar. ${ }^{30}$

\footnotetext{
${ }^{24}$ Ibid., 148.

${ }^{25}$ Ibid., 148-149.

${ }^{26}$ MEED, March 26, 1988.

${ }^{27}$ Azzam, Gulf Economies in Transition, 150-151.

${ }^{28}$ MEED, May 3, 1991.

${ }^{29}$ MEED, December 20, 1991; Middle East Memo, October 30, 1992.

${ }^{30}$ MEED, February 14, 1992.
} 
By mid-1992, the postwar flowering of economic regionalism had started to wither. The Ministerial Council decided in early June to entrust the management of the newly-created assistance fund to the central bank of Saudi Arabia. The council also announced that no regional customs union could be expected to emerge until at least the year 2000. ${ }^{31}$ Since the European Union had demanded that a GCC common market be set up as a precondition for reducing barriers to trade between the two entities, the six ministers of industry advised the GCC secretariat to stop focusing on trade negotiations with Europe and instead "shift our sights to other [regional] groupings in the world." ${ }^{32}$ When external investment in local manufacturing rebounded that fall, Saudi Arabia and the UAE stepped up their efforts to manipulate tariffs as a way to promote domestic industry. ${ }^{33}$ More important, the Saudi delegate to a September 1994 conference of GCC finance ministers reported that his colleagues had "agreed that finding a fixed exchange rate for GCC currencies is no longer the priority it had been some years ago. Since the establishment of the GCC," he continued, "exchange rates have remained stable even without a written accord." 34

Nevertheless, the mid-1990s witnessed a renewed outburst of economic regionalism. In September 1994, Bahrain's Chamber of Commerce opened a center for the arbitration of intra-GCC commercial disputes, whose board of governors included representatives from the chambers of commerce and industry of all six member-states. ${ }^{35}$ The GCC opted to become a full partner in the International Mobile Satellite Organization at the end of 1994-a move that committed the six countries to permit unrestricted use of cellular telephones across their common borders. ${ }^{36}$ About the same time, special GCC commissions approved measures that equalized handling charges for the unloading of cargo at local airports and granted GCC citizens the right to buy and sell corporate shares offered in any GCC stock market. ${ }^{37}$ The six finance ministers met in Riyadh in March 1995 and agreed to link automated teller machines across the GCC, eliminate restrictions that kept citizens from applying for loans at GCC banks outside their home countries, and "undertake economic activities in the educational field." 38 Six months later, the AGOIC published a comprehensive prospectus that was designed to persuade

\footnotetext{
${ }_{31}$ MEED, June $12,1992$.

${ }^{32}$ MEED, November 6, 1992.

${ }^{33}$ MEED, November 13, 1992, and December 4, 1992.

${ }^{34}$ MEED, September 30, 1994.

${ }^{35}$ MEED, September 9, 1994.

${ }^{36}$ MEED, December 9, 1994.

${ }^{37}$ MEED, January 6, 1995.

${ }^{38}$ MEED, April 7, 1995.
} 
European companies to invest in complementary mineral extraction ventures in the six member-states. ${ }^{39}$

Substantial portions of the 1995 and 1996 Supreme Council agendas were devoted to exploring joint responses to regional economic problems, particularly the troublesome question of how to generate enough attractive jobs for the GCC's rapidly expanding population of well-educated young people. ${ }^{40}$ At the 1997 summit, plans were approved to connect the member-states' electricity grids and to allow banks chartered in any one GCC state to open branches in all of the others. ${ }^{41}$ The resurgence of multilateralism was even apparent in talks concerning the formation of a customs union. Despite indications in late 1996 that the Ministerial Council had abandoned all hope of adopting unified tariff regulations for the foreseeable future, the project continued to be debated during the course of $1997 .{ }^{42}$ Ironically, the major sticking-point in the negotiations at that point was the UAE's refusal to raise tariffs to match the proposed uniform rate of $8 \% .{ }^{43}$

This period of resurgent economic regionalism along the Arab coast of the Gulf displayed a quite different mix of attributes from the one that characterized the early years of the GCC's existence. In spite of the activities of the AGOIC, the organization drifted from the fourth to the third column of Figure 1. Despite sporadic expressions of intent to place authority over a wider range of economic issues in the hands of the GCC secretariat, it seems safe to say that policies regarding important economic matters could not actually be adopted and implemented by GCC agencies acting on their own.

More importantly, by the mid-1990s, the original decision-making rule of unanimity in the Supreme and Ministerial Councils had effectively been abandoned, in practice if not in principle. One or another member-state from time to time withheld consent to some proposed GCC program without blocking or derailing the overall project of greater economic integration. Only Saudi Arabia had the capacity and authority to exercise a veto over the adoption or implementation of proposed regionalist initiatives.

\section{Second Regression}

Economic regionalism among the GCC states stalled once again as the 1990s waned. Writing in 2001, Humayon Dar and John Presley remark that "progress toward a

\footnotetext{
${ }^{39}$ MEED, October 27, 1995.

${ }^{40}$ John Duke Anthony, "Points, Patterns, Prognosis: The 17th GCC Heads of State Summit and Aftermath" Occasional Paper 8 (Washington, D. C.: US-GCC Corporate Cooperation Committee and National Council on US-Arab Relations, 1996), 167 and 176.

${ }^{41}$ Faris Glubb, "The GCC: Important Steps Forward," Middle East International 566 (January 16, 1998).

${ }^{42}$ MEED, November 8, 1996, and July 11, 1997.

${ }^{43}$ Middle East Executive Reports, October 1997.
} 
common external tariff has been very slow despite pressures to present a unified front, particularly over trade with the European Union and as part of a negotiating stance for membership of [sic] WTO for all member states." ${ }^{44}$ Furthermore, "after 20 years of operation ... the share of intra-regional trade in the GCC has only increased from five per cent in 1982 to a little over seven per cent by 2000." ${ }^{45}$ Rather than tending to converge over time, GCC regulations governing external trade and investment practices actually diverged from the relatively parallel ones that were adopted by individual member-states during the late 1990s. ${ }^{46}$

Measures designed to revive Arab Gulf regionalism continued to be announced periodically, even though none of them generated sustained momentum toward economic integration. The Middle East Economic Digest reported that at the December 2000 meeting of the Supreme Council, the long-debated customs union "was discussed but rejected" and "lip-service was also paid to the establishment of a single currency, which was approved in principle." ${ }^{\prime 7}$ In January 2001, the GCC secretariat announced that Saudi Arabia and Qatar had pledged to reduce duties on imports of a variety of goods produced in other member-states, as a first step toward the construction of a working Gulf customs union. ${ }^{48}$ At the end of the year, the Supreme Council fixed the projected common external tariff at $5 \%$ and advanced the date for the inauguration of the customs union from January 2005 to January 2003. ${ }^{49}$

Finance, economy, and trade ministers from the six member-states gathered in Doha in December 2002 to put the finishing touches on the planned customs union. The host country's minister of finance emerged from the meeting to report that "all obstacles were removed," and that the union would come into force the following month..$^{50} \mathrm{He}$ went on to announce that the GCC intended to set up a common market by the fall of 2010. Nevertheless, the organization's secretary general in January 2004 told reporters that no more than "the first phase" of the plan to establish a full customs union had been accomplished so far, and that a second year-long preparatory phase was about to get underway. ${ }^{51}$

Even as the secretary general was speaking, Bahrain and Oman were engaged in negotiating bilateral free trade agreements with the United States. Talks between

\footnotetext{
${ }^{44}$ Humayon A. Dar and John R. Presley, “The Gulf Co-operation Council: A Slow Path to Integration?” World Economy 24, no. 9 (September 2001): 1162.

${ }^{45}$ Ibid., 1163.

${ }^{46}$ Ibid., 1164.

${ }^{47}$ MEED, January 12, 2001.

${ }^{48}$ ArabicNews.com, January 11, 2001.

${ }^{49}$ Arab News, January 1, 2002; Matteo Legrenzi, "Did the GCC Make a Difference? Institutional Realities and (Un)Intended Consequences," in Beyond Regionalism? Regional Cooperation, Regionalism and Regionalization in the Middle East, eds., Cilja Harders and Matteo Legrenzi (Aldershot: Ashgate, 2008), 116-117.

${ }^{50}$ Arab Nerws, December 16, 2002.

${ }^{51}$ Gulf Newws, January 14, 2004.
} 
Manama and Washington reached a mutually satisfactory conclusion in September 2004, and the two governments signed a free trade pact two months later. Saudi officials quickly condemned the treaty, calling it a "clear violation of the GCC's economic accords and decisions." ${ }^{52}$ Public vituperation on Riyadh's part, however, failed to frighten remaining member-states away from pursuing similar kinds of commercial arrangements; talks between the US and Oman proceeded apace, while the UAE initiated discussions with Washington in February 2005. ${ }^{53}$ Faced with growing interest in such treaties on the part of Qatar and Kuwait, the Saudi government relented, and, in May 2005, the six finance ministers agreed that GCC member-states would be permitted to set up bilateral free trade areas with outside countries. $^{54}$

Economic regionalism suffered a more pronounced setback in December 2006, when Oman unexpectedly withdrew from the initiative to create a single GCC currency. Confronted with Oman's defection, Saudi Arabia's finance minister observed that plans to create a unified regional currency by 2010 had begun to look overly "ambitious." 55 Five months later, Kuwait abruptly stopped pegging the value of its currency to that of the US dollar, in accordance with common practice among the GCC states, and started to peg it instead to a basket of major world currencies. ${ }^{56}$ The combination of these two events left the longstanding plan to introduce a unified Gulf currency effectively "moribund." ${ }^{7}$

\section{Regionalism Redux}

On the other hand, in January 2008, the Supreme Council formally inaugurated the GCC common market, which promised to allow the unrestricted movement of goods, capital, and labor across the borders of the six member-states. ${ }^{58}$ This new regionalist initiative was predicated on the cardinal principle that a citizen of one member-state enjoys full citizenship rights in all other GCC countries. "The common market thus endows GCC citizens with equal treatment in respect of all economic activities, particularly, movement and residence. It allows GCC citizens to work in private and public sectors in each Member State as well as to receive any applicable welfare

\footnotetext{
${ }^{52}$ Agence France Presse, December 18, 2004; Bessma F. Al-Momani, "Reacting to Global Forces: Economic and Political Integration of the Gulf Cooperation Council," Journal of the Gulf and Arabian Peninsula Studies 128 (January 2008): 57.

${ }^{53}$ Riad Kahwaji, “Mideast Initiative Called Threat to GCC Unity," Defense Newws, March 28, 2005.

${ }^{54}$ MEED, June 3, 2005.

${ }^{55}$ Gulf News, December 12, 2006.

${ }^{56}$ Gulf Neww, June 7, 2007; Eckart Woertz, "To Peg or Not to Peg” (Dubai: Gulf Research Center, 2007).

${ }^{57}$ Joseph A. Kechichian, "A Relevant GCC Summit," Gulf Nerws, October 31, 2007.

${ }^{58}$ Agence France Presse, January 3, 2008.
} 
benefits such as pension and social security payments. ${ }^{59}$ Persistent disagreements over the mechanisms whereby customs revenues were to be collected and distributed subsequently pushed the customs union's full implementation date from 2010 to $2013 .{ }^{60}$

Nevertheless, the inauguration of the common market accompanied a slow but steady rise in regional economic and occupational mobility among GCC citizens. By 2010, some 21,000 nationals had taken up permanent employment "in a GCC state other than their country of origin." ${ }^{11}$ For the most part, GCC expatriates were attracted to professional and commercial opportunities in Qatar, Kuwait, and the UAE, and were drawn away from Bahrain and Oman, whose economies have been characterized by much tighter job markets for white collar workers.

Arguably more importantly, the GCC secretariat announced plans to create an independent tribunal that would possess the authority to adjudicate commercial disputes. ${ }^{62}$ The new judicial body was envisaged as having the ability to impose penalties on companies and individuals whose actions contravened the terms of GCC economic agreements. In early 2009, the UAE persuaded the Supreme Council to set up a high commission to oversee the implementation of the customs union. This commission was tasked with harmonizing rules of origin across the six member-states, as well as with working out a mutually acceptable mechanism whereby domestic producers could be protected against foreign competition. ${ }^{63}$ In May of that year, a GCC risk management center was opened in Kuwait, whose staff was charged with monitoring and assessing threats to the region that might arise from the outbreak of epidemics or the occurrence of natural disasters. ${ }^{64}$

In early June 2009, senior financial officials from Saudi Arabia, Kuwait, Bahrain, and Qatar met in Riyadh to sign the agreement creating a GCC Monetary Council, and were charged with laying out the procedural framework that would guide the establishment of a regional central bank. ${ }^{65}$ The accord specifically prohibited the central banks of the six GCC member-states from "giving any instructions to the GCC Central Bank ... in order to secure the independence of the GCC

\footnotetext{
${ }^{59}$ Gonzalo Villalta Puig and Bader A1-Haddab, "The Constitutionalisation of Free Trade in the Gulf Cooperation Council," Arab Law Quarterly 25, no. 3 (2011): 317.

${ }^{60}$ Gulf Nerws, September 7, 2010.

${ }^{61}$ Zahra R. Babar, "Free Mobility within the Gulf Cooperation Council," CIRS Occasional Paper 8 (Doha: Center for International and Regional Studies, Georgetown University School of Foreign Service in Qatar, 2011), 4.

${ }^{62}$ MEED, January 4-10, 2008.

${ }^{63}$ Linda Low and Lorraine Carlos Salazar, "The Gulf Cooperation Council: A Rising Power and Lessons for ASEAN," ISEAS Report no. 12 (Singapore: ASEAN Studies Centre, Institute of Southeast Asian Studies, 2011), 21.

${ }^{64}$ Ibid., 51.

${ }^{65}$ Arab News, June 8, 2009.
} 
Central Bank." ${ }^{66}$ In addition, the new regional bank was explicitly empowered "to levy financial sanctions and impose them on the accounts of the national central banks at the [GCC] Central Bank when these national central banks violate their commitments, which are undertaken on the basis of the decisions or instructions of the Central Bank." ${ }^{\prime 7}$

Meanwhile, three kinds of regional infrastructure took shape under the auspices of the GCC. The first was a unified pipeline network to distribute natural gas among the six member-states. Bahrain took the leading role in advocating the construction of the pipeline, partly to ensure that its own domestic aluminum plants would enjoy a stable supply of natural gas and partly to facilitate the completion of a new fertilizer complex operated by the Gulf Petrochemical Industries Company-a joint venture of the Bahraini government, the Petrochemical Industries Company of Kuwait, and Saudi Arabia Basic Industries Corporation. ${ }^{68}$ The second was an integrated regional railway system, which was designed to stretch from the Kuwait-Iraq border in the north to the Omani port of Salalah in the south and to incorporate the most important rail lines inside Saudi Arabia. As part of this extensive project, which was estimated to cost some US $\$ 25$ billion, the proposed causeway linking Bahrain and Qatar was redesigned to accommodate regular train traffic, so that Bahrain could be incorporated into the railway system. ${ }^{69}$ The Supreme Council pointedly reaffirmed its commitment to completing the regional railroad network at its December 2010 meeting.

Third, 2010 saw the inauguration of a unified electrical power grid connecting GCC member-states. Kuwait, Bahrain, Qatar, and Saudi Arabia boasted a fully integrated electricity distribution network that spring, and transmission lines across the desert to the UAE and Oman moved into the final phase of construction during the second half of the year. ${ }^{70}$ At the same time that the electrical lines were laid, fiber optic cables were put in place, raising the possibility that an integrated GCC telecommunications network might coalesce at last. In addition to the unified grid, the GCC secretariat set up a specialized agency, the GCC Interconnection Authority (GCCIA), responsible for supervising the generation and distribution of electrical power across the region. The GCCIA was expected to "act as the regulator and manage the flows of electricity through the network once two states negotiate a deal." ${ }^{\text {11 }}$ Agency officials immediately sat down to draw up the technical terms and

\footnotetext{
${ }^{66}$ Salman Dossari, "Details of GCC Monetary Union Agreement," Al-Sharq Al-Awsat, October 13, 2009.

${ }^{67}$ Ibid.

${ }^{68}$ MEED, May 30-June 5, 2008.

${ }^{69}$ MEED, March 13-19, 2009; Kuwait Times, January 3, 2010.

${ }^{70}$ MEED, July 9-15, 2010.

${ }^{71}$ Ibid.
} 
administrative procedures that would be used to govern the sale and distribution of electricity among the GCC countries.

Greater regionalist activism emerged among the chambers of commerce and industry as well. Some 15,000 licenses to conduct business in another GCC country had been awarded to companies in the six member-states by the end of 2005. These cross-border businesses gained momentum during the second half of the decade, and gradually transformed the chambers of commerce and industry into outspoken proponents of greater economic integration. In October 2011, for example, Qatar's Chamber of Commerce and Industry presented to the Technical Committee for Land Transport of the Federation of GCC Chambers a proposal to form a single GCC land transportation company. Such a company, the Qatari delegation argued, could be expected to "facilitate transport flow, organise cargoes and manage drivers' affairs, such as issuing visas." 72

Regionalist initiatives on the part of private businesspeople were buttressed by the activities of the reinvigorated AGOIC, whose officials convened a gathering of GCC producers of pharmaceuticals and medical supplies in June 2011, for instance, and provided the seed money necessary for these manufacturers to set up a trade federation to promote their common economic and regulatory interests. The nascent federation was given sufficient resources to operate for a year, during which time it was expected to attract enough dues-paying members to become a self-sustaining organization. Among other objectives, the federation committed itself to standardizing products and industrial processes across the region, as well as facilitating the growth of "industrial linkages" among GCC-based enterprises. ${ }^{73}$

Regionalist initiatives on the part of private companies accompanied an unprecedented jump in investments from one member-state to another. Between 1990 and 2003, less than US $\$ 3.6$ billion had been invested in the Arab Gulf states by local economic actors. By 2009, however, "the amount of cross-border investments [had] increased significantly, especially in the telecom sector." ${ }^{74}$ Many of these investments involved mergers and acquisitions. A report prepared by the management consulting firm Booze and Company observed that "intra-GCC M\&A [mergers and acquisitions] activity has been quite robust across all industry sectors, growing to $\$ 26.4$ billion between 2000 and 2008." 75 The largest share of acquisitions during these years accrued to companies based in Kuwait and Qatar, while most targets for

\footnotetext{
${ }^{72}$ Gulf Times, October 17, 2011.

${ }^{73}$ Business Monitoring International, July 1, 2011.

${ }^{74}$ Richard Shediac, Parag Khanna, Taufiq Rahim, and Hatem A. Samman, "Integrating, Not Integrated: A Scorecard of GCC Economic Integration” (Abu Dhabi: Booze and Company, 2011), 16.

75 Ibid., 16.
} 
mergers were located in Saudi Arabia, Kuwait, and the UAE. Such investments were accorded an added fillip by the Supreme Council in December 2010, when the six rulers approved regulations permitting companies based in one GCC country to set up branches in other member-states "on an equal footing with national firms." 76

By the second decade of the twenty-first century, the Gulf Cooperation Council had become transformed into a very different type of regionalist project from what it had been either in 1981, when the GCC was founded, or during the mid-1990s. There continued to be significant incentives for the six member-states to collaborate with one another, most notably on the long-awaited free trade area; pronounced steps in the direction of greater interdependence were being taken, both under the auspices of the AGOIC and through the activities of local chambers of commerce and industry. At the same time, unanimity in policy-making had been supplanted by a unitary veto system, while authority over policies concerning regional infrastructure had begun to be transferred into the hands of a collection of specialized supervisory agencies. These trends put the contemporary GCC squarely in the fourth column and fifth row of the analytical matrix contained in Figure 1.

\section{Explanations for Changes in Types of Regionalism}

Four theoretical arguments offer plausible alternative explanations for the transformations of regional economic governance that have taken place in the Gulf Cooperation Council since 1981. The first links regionalist initiatives to outbreaks of domestic political conflict. Both the initial formation of the GCC and the resumption of regionalist momentum during the mid-1990s took place at times when the regimes of the six member-states confronted severe internal challenges. Under these circumstances, GCC rulers cracked down on domestic challengers while at the same time introducing innovative regional economic arrangements. These measures promised to further the interests of local entrepreneurs and professionals and thereby persuade these forces not to align themselves with radical movements. ${ }^{77}$ It is quite possible that the marked upturn in GCC regionalism during 2008-2009 can be traced to a resurgence of domestic political challenges across the region. Simmering unrest in Bahrain, along with escalating conflict between the ruling family and the National Assembly in Kuwait, and percolating labor unrest in the UAE and Saudi Arabia, may well have set the stage for a pronounced rejuvenation of regional economic governance along the Arab shore of the Gulf.

\footnotetext{
${ }^{76}$ Gulf Nerws, June 9, 2011.

${ }^{77}$ Lawson, "Theories of Integration," 20.
} 
Second, the scholarship on regionalism in East Asia underscores the impact that broad trends in the global economy have on the structure of commercial and financial relations among member-states of regional formations. In particular, there is general consensus that the Asian crisis of 1997-1998 not only propelled governments toward heightened levels of regional economic governance under the auspices of the Association of Southeast Asian Nations (ASEAN), but also laid the foundation for enhanced collaboration between ASEAN and the countries of northeast Asia. ${ }^{78}$ Precisely how global dynamics shape regional outcomes remains unclear. Hidetaka Yoshimatsu argues that developments in the outside world prompt one or two member-states to assume the role of "focal points" with regard to coordination problems of regional importance. ${ }^{79}$ Since cooperation is much easier for pairs of actors than it is for larger numbers, initiatives undertaken by the two focal points have a tendency to "showcase these bilateral projects and their results, to encourage other members [of the regional formation] to join in." ${ }^{80}$ Moments of accelerated regionalism can thus be traced directly to bilateral initiatives, which most often reflect the interests of the two countries involved rather than the collective interest of the region.

Third, bursts of heightened economic regionalism seem most likely to take place only after cross-border infrastructure reaches the point at which collective industrial and commercial expansion can be sustained. Common indicators of regionalist activity, such as the level of intra-regional trade and investment, rely on the existence of networks of transportation and communication that determine the "logistics costs" associated with transactions among member-states. ${ }^{81}$ Until these costs become manageable, calls for expanded intra-regional exchange are unlikely to have any actual impact. Furthermore, higher levels of regional trade and investment depend on the consolidation of two distinct kinds of infrastructure: "hardware" and "software." The former includes such physical facilities as seaports, railways, and electrical transmission lines; the latter consists of the "legal, regulatory, procedural, and

\footnotetext{
${ }_{78}$ Kazushi Shimizu, “The Asian Economic Crisis and Intra-ASEAN Economic Cooperation," Economic Journal of Hokkaido University 29 (2000); Hidetaka Yoshimatsu, "Political Leadership, Informality, and Regional Integration in East Asia: The Evolution of ASEAN Plus Three," European Journal of East Asian Studies 4, no. 2 (September 2005); John Ravenhill, "Fighting Irrelevance: An Economic Community 'with ASEAN Characteristics," The Pacific Review 21, no. 4 (December 2008).

${ }^{79}$ Hidetaka Yoshimatsu, "Collective Action Problems and Regional Integration in ASEAN," Contemporary Southeast Asia 28, no. 1 (April 2006): 130.

${ }^{80}$ Ibid.

${ }^{81}$ Haruhiko Kuroda, Masahiro Kawai and Rita Nangia, "Infrastructure and Regional Cooperation," ADB Institute Discussion Paper 76 (Tokyo: Asian Development Bank Institute, September 2007), 5. See also Biswa Nath Bhattacharyay, "Infrastructure for ASEAN Connectivity and Integration," ASEAN Economic Bulletin 27, no. 2 (August 2010).
} 
other supporting policy frameworks" that facilitate joint economic activity. ${ }^{82}$ Given the fact that the benefits that states derive from the development of cross-border infrastructure are almost always "indirect and long term, whereas costs tend to be incurred immediately and up front," infrastructural projects have the characteristics of public goods. ${ }^{83}$ They are therefore most likely to be undertaken either at the initiative of the dominant state in any regional grouping, or as a succession of bilateral arrangements. Saudi Arabia's recent efforts to promote the railroad network and electricity grid not only illustrate the reinvigoration of economic regionalism, but provide the impetus for greater momentum toward Arab Gulf integration.

Finally, and paradoxically, the emergence of fully articulated regional governance accompanies the consolidation, rather than the undermining, of the administrative apparatuses of member-states. Comparatively weak and vulnerable states may well take steps to create regional formations as a way to prop themselves up, particularly in the face of severe domestic challenges. It is only when such states begin to overcome their fragility, however, that they have an incentive to relinquish a portion of their hard-won sovereignty and transfer policy-making authority to supranational institutions. State weakness usually goes hand in hand with the inefficient use of resources, which deprives governments of the capacity to maintain regional institutions. ${ }^{84}$ Furthermore, weak states find themselves threatened by actual and prospective regional partners that could exploit temporary gains from mutual collaboration for their own economic and strategic advantage. As a result, until member-states accrue sufficient institutional strength and coherence, regionalist projects can be expected to remain little more than "mutual sovereignty reinforcement coalitions, not integrationist regional bodies like the European Union." ${ }^{85}$ The gradual consolidation of administrative apparatuses across the GCC countries, and the nascent divergence of state interests from the interests of ruling families, ${ }^{86} \mathrm{can}$ therefore be connected to the current burst of regional economic governance.

\section{Conclusion}

Regionalist projects all over the world espouse broadly similar objectives and deploy almost identical rhetorical tropes in their founding documents and official

\footnotetext{
${ }^{82}$ Kuroda, Kawai, and Nangia, "Infrastructure and Regional Cooperation," 7.

${ }^{83}$ Ibid., 16.

${ }^{84}$ Christopher Roberts, "ASEAN Institutionalisation: The Function of Political Values and State Capacity," RSIS

Working Paper 217 (Singapore: S. Rajaratnam School of International Studies, December 2010), 6.

${ }^{85}$ Robert E. Kelly, "Security Theory in the 'New Regionalism," International Studies Review 9, no. 2 (June 2007): 218.

${ }^{86}$ Fred H. Lawson, "Economic Liberalization and the Reconfiguration of Authoritarianism in the Arab Gulf States," Orient 46, no. 1 (2005).
} 
pronouncements. Moreover, nearly every regional economic formation explicitly preserves the fundamental prerogatives of member-states, and as a result exercises authority over few, if any, major economic matters. Yet, the institutional arrangements and procedural rules that characterize disparate regional formations vary widely from one case to another. Such differences provide the foundation for sharply divergent developmental trajectories, and may even determine whether particular regional entities survive and flourish, or, instead, stagnate and collapse.

In the Middle East and North Africa, a variety of regionalist experiments can be adumbrated. All of them claim to champion Arab unity, and the great majority also calls for an end to government restrictions on the flow of regional trade, investment, and labor. Moreover, and somewhat contradictorily, they tend to insist on protecting the sovereignty of member-states, while adhering to the Westphalian principles of self-determination and non-intervention in domestic economic affairs. This combination of principles has prompted Michael Barnett and Etel Solingen to conclude that Arab regional formations have, for the most part, been "designed to fail." ${ }^{~} 7$

Regionalist projects nevertheless differ from one another in crucial ways. Some provide member-states with incentives that can induce them to fall in with initiatives that are designed to promote regional interests and priorities, while others rely on individual states to encourage or enforce multilateralist programs. Some actively encourage higher levels of interdependence among member-states, while others offer little or no support for measures that increase intra-regional interdependence. Most regional formations operate according to a rule of unanimity in policy-making, thereby preserving the sovereign rights of member-states. Nevertheless, at least one notable regionalist project, the Arab Cooperation Council, operated from the outset on the basis of majority rule. ${ }^{88}$

Over the last three decades, the Gulf Cooperation Council has exhibited a remarkable developmental trajectory, which all-too-often gets overlooked or dismissed by outside observers who tend to claim flatly that the organization has failed to live up to expectations. The GCC began as a regionalist project that intended to increase the level of interdependence among its six member-states, while offering a strong institutional incentive for sustained collaboration in the form of a proposed free trade area. This mix of features closely resembled that of the early Arab Maghreb Union, except that AMU governments devolved no policy-making

\footnotetext{
${ }^{87}$ Michael Barnett and Etel Solingen, "Designed to Fail or Failure of Design? The Sources and Institutional Effects of the Arab League," in Crafting Cooperation: Regional Institutions in Comparative Perspective, eds., Alastair Iain Johnston and Amitav Acharya (Cambridge: Cambridge University Press, 2007).

${ }^{88}$ Lawson, "Comparing Regionalist Projects," 26-27.
} 
authority onto a supranational agency. ${ }^{89}$ By the mid-1990s, the GCC had moved away from the campaign to augment interdependence among member-states, and had effectively replaced the decision rule of unanimity with a unitary veto in the hands of Saudi Arabia. At the same time, whatever policy-making authority had earlier been accorded to the GCC secretariat and its various functional agencies evaporated, leaving regionalist initiatives firmly in the hands of the Supreme Council.

By 2010, however, the GCC started to exhibit yet a third institutional configuration. Incentives for member-states to collaborate in the overall regionalist project remain at best moderate, but measures aimed at increasing the level of interdependence among the six economies have once again been placed on the agenda. Unanimous consent continues to be unnecessary in order for regionalist initiatives to be adopted and implemented, while supranational agencies have begun to acquire a measure of policy-making authority over sectors of the regional economy that had previously been governed exclusively by individual states.

In this respect, the Gulf Cooperation Council has come to resemble regionalist projects in other parts of the world - ones that analysts usually claim demonstrate a high degree of economic integration and multilateralism. Determining whether or not today's Gulf Cooperation Council shares structural and procedural features with, and thereby belongs in the same cell of Figure 1 as, such dynamic regional formations as the Association of Southeast Asian Nations, the Mercado Comun del Sur (MERCOSUR), or the Eurasian Economic Community ${ }^{90}$ will require rigorous comparative inquiry.

\footnotetext{
${ }^{89}$ Ibid., 25-26.

${ }^{90}$ Shaun Narine, Explaining ASEAN (Boulder, Colo.: Lynne Rienner, 2002); Rodolfo C. Severino, "ASEAN Beyond Forty: Towards Political and Economic Integration," Contemporary Southeast Asia 29, no. 3 (October 2007); Nicola Phillips, "Regionalist Governance in the New Political Economy of Development: 'Relaunching' the Mercosur," Third World Quarterly 22, no. 4 (August 2001); Laura Gomez-Mera, "How 'New' is the 'New Regionalism' in the Americas? The Case of MERCOSUR," Journal of International Relations and Development 11, no. 3 (September 2008); Ikboljon Qoraboyev, "From Central Asian Regional Integration to Eurasian Integration Space? The Changing Dynamics of Post-Soviet Regionalism," Eurasian Integration Yearbook 2010 (Almaty: Eurasian Development Bank, 2010), 206-232.
} 


\section{BIBLIOGRAPHY}

Al-Fayez, Khaled. "The Gulf Investment Corporation." American-Arab Affairs 11 (Winter 1984-1985): 34-37.

Al-Momani, Bessma F. "Reacting to Global Forces: Economic and Political Integration of the Gulf Cooperation Council." Journal of the Gulf and Arabian Peninsula Studies 128 (January 2008): 47-66.

Al-Yousuf, Ala'a. "Industrialisation and Economic Integration in the Arab Gulf." Arab GulfJournal 6, no. 3 (April 1986): 25-31.

Anthony, John Duke. "Points, Patterns, Prognosis: The 17th GCC Heads of State Summit and Aftermath.” Occasional Paper 8. Washington, D.C.: US-GCC Corporate Cooperation Committee and National Council on US-Arab Relations, 1996.

Antoniades, Alexis. "The Gulf Cooperation Council Monetary Union." In The Political Economy of the Persian Gulf, edited by Mehran Kamrava. New York/London: Columbia University Press/Hurst, 2012.

Azzam, Henry T. The Gulf Economies in Transition. New York: St. Martin's, 1988.

Babar, Zahra R. "Free Mobility within the Gulf Cooperation Council." CIRS Occasional Paper 8. Doha: Center for International and Regional Studies, Georgetown University School of Foreign Service in Qatar, 2011.

Baldwin,David A. "Interdependence and Power: A Conceptual Analysis." International Organization 34, no. 4 (Autumn 1980): 471-506.

Barnett, Michael, and Etel Solingen. "Designed to Fail or Failure of Design? The Sources and Institutional Effects of the Arab League." In Crafting Cooperation: Regional Institutions in Comparative Perspective, edited by Alastair Iain Johnston and Amitav Acharya, 180-220. Cambrdige: Cambridge University Press, 2007.

Barnett, Michael, and F. Gregory Gause III. "Caravans in Opposite Directions: Society, States and the Development of Community in the Gulf Cooperation Council." In Security Communities, edited by Emanuel Adler and Michael Barnett, 161-197. Cambridge: Cambridge University Press, 1998.

Beseisu, Fouad Hamdi. "Sub-regional Economic Cooperation in the Arab Gulf." Arab Gulf Journal 1, no. 1 (October 1981): 45-54.

Best, Edward. "The Assessment of Regional Governance: Principles, Indicators and Potential Pitfalls." UNU-CRIS Working Paper 2008/10. Bruges: Comparative Regional Integration Studies, United Nations University, 2008. 
Bhattacharyay, Biswa Nath. "Infrastructure for ASEAN Connectivity and Integration." ASEAN Economic Bulletin 27, no. 2 (August 2010): 200-220.

Bishara, Abdulla Yacoub. "The Gulf Cooperation Council: Achievements and Challenges." American-Arab Affairs 7 (Winter 1983-1984): 40-44.

“Charter." American-Arab Affairs 7 (Winter 1983-1984): 157-176.

Christie, John. "History and Development of the Gulf Cooperation Council." American-Arab Affairs 18 (Fall 1986): 1-13.

Cordesman, Anthony H. The Gulf and the Search for Strategic Stability. Boulder, Colo.: Westview Press, 1984.

Dar, Humayon A., and John R. Presley. "The Gulf Co-operation Council: A Slow Path to Integration?” World Economy 24, no. 9 (September 2001): 1161-1178.

Dossari, Salman. "Details of GCC Monetary Union Agreement." Al-Sharq Al-Awsat. October 13, 2009.

Elliott, Lorraine, and Shaun Breslin. Comparative Environmental Regionalism. Abingdon: Routledge, 2011.

Foot, Rosemary. "The Role of East Asian Regional Organizations in Regional Governance: Constraints and Contributions." Carnegie Endowment for International Peace. June 7, 2011. http://carnegieendowment.org/2011/06/07/ role-of-east-asian-regional-organizations-in-regional-governance-constraintsand-contributions $/ 1 \mathrm{kqn}$.

Glubb, Faris. "The GCC: Important Steps Forward." Middle East International 566 (January 16, 1998): 15-16.

Gomez-Mera, Laura. "How 'New' is the 'New Regionalism' in the Americas? The Case of MERCOSUR." Journal of International Relations and Development 11, no. 3 (September 2008): 279-308.

Heard-Bey, Frauke. Die arabischen Golfstaaten im Zeichen der islamischen Revolution. Bonn: Europa Verlag, 1983.

Hitiris, Theodore, and Michael H. Hoyle. "Monetary Integration in the GCC: An Evaluation." Arab Gulf Journal 6, no. 1 (October 1986): 33-42.

Hunter, Shireen T. "The Gulf Economic Crisis and its Social and Political Consequences." Middle East Journal 40, no. 4 (Autumn 1986): 593-613.

Kahler, Miles, and David A. Lake. "Economic Integration and Global Governance: Why So Little Supranationalism?" In The Politics of Global Regulation, edited by Walter Mattli and Ngaire Woods, 242-275. Princeton: Princeton University Press, 2009. 
Kahwaji, Riad. "Mideast Initiative Called Threat to GCC Unity." Defense Nerws. March 28, 2005.

Kechichian, Joseph A. “A Relevant GCC Summit.” Gulf Nerws. October 31, 2007.

Kelly, Robert E. "Security Theory in the 'New Regionalism." International Studies Review 9, no. 2 (June 2007): 197-229.

Kuroda, Haruhiko, Masahiro Kawai and Rita Nangia. "Infrastructure and Regional Cooperation.” ADB Institute Discussion Paper 76. Tokyo: Asian Development Bank Institute, September 2007.

Lawson, Fred H. Babrain: The Modernization of Autocracy. Boulder, Colo.: Westview Press, 1989.

. "Theories of Integration in a New Context: The Gulf Cooperation Council." In Racing to Regionalize, edited by Kenneth P. Thomas and Mary Ann Tétreault, 7-31. Boulder, Colo.: Lynne Rienner, 1999.

_- "Managing Economic Crises: The Role of the State in Bahrain and Kuwait." Studies in Comparative International Development 26, no. 1 (Spring 1991): 43-67.

the Arab Gulf States." Orient 46, no. 1 (2005): 19-43.

. "Comparing Regionalist Projects in the Middle East and Elsewhere: One Step Back, Two Steps Forward." In Beyond Regionalism? Regional Cooperation, Regionalism and Regionalization in the Middle East, edited by Cilja Harders and Matteo Legrenzi, 13-31. Aldershot: Ashgate, 2008.

Legrenzi, Matteo. “The Long Road Ahead: Economic Integration in the Gulf States.” Cooperation South (2003): 33-45.

. "Did the GCC Make a Difference? Institutional Realities and (Un)Intended Consequences." In Beyond Regionalism? Regional Cooperation, Regionalism and Regionalization in the Middle East, edited by Cilja Harders and Matteo Legrenzi, 107-124. Aldershot: Ashgate, 2008.

- The GCC and the International Relations of the Gulf. London: I. B. Tauris, 2011.

Lindberg, Leon N. "Political Integration as a Multi-Dimensional Phenomenon Requiring Multivariate Measurement." International Organization 24, no. 4 (Autumn 1970): 649-731.

Low, Linda, and Lorraine Carlos Salazar. "The Gulf Cooperation Council: A Rising Power and Lessons for ASEAN.” ISEAS Report 12. Singapore: ASEAN Studies Centre, Institute of Southeast Asian Studies, 2011. 
Narine, Shaun. Explaining ASEAN. Boulder, Colo.: Lynne Rienner, 2002.

Nesadurai, Helen E. S. "ASEAN and Regional Governance after the Cold War." The Pacific Review 22, no. 1 (March 2009): 91-118.

Nye, Joseph. "Comparative Regional Integration: Concept and Measurement." International Organization 22, no. 4 (Autumn 1968): 855-880.

Nye, Roger. "Political and Economic Integration in the Arab States of the Gulf." Journal of South Asian and Middle Eastern Studies 2, no. 1 (Fall 1978): 3-21.

Peterson, Erik R. The Gulf Cooperation Council. Boulder, Colo.: Westview, 1988.

Phillips, Nicola. "Regionalist Governance in the New Political Economy of Development: 'Relaunching' the Mercosur." Third World Quarterly 22, no. 4 (August 2001): 565-583.

Priess, David. "Balance-of-Threat Theory and the Genesis of the Gulf Cooperation Council." Security Studies 5, no. 4 (Summer 1996): 143-171.

Puig, Gonzalo Villalta, and Bader Al-Haddab. "The Constitutionalisation of Free Trade in the Gulf Cooperation Council." Arab Law Quarterly 25, no. 3 (2011): 311-324.

Qoraboyev, Ikboljon. "From Central Asian Regional Integration to Eurasian Integration Space? The Changing Dynamics of Post-Soviet Regionalism." Eurasian Integration Yearbook 2010, 206-232. Almaty: Eurasian Development Bank, 2010.

Ravenhill, John. "Fighting Irrelevance: An Economic Community 'with ASEAN Characteristics." The Pacific Review 21, no. 4 (December 2008): 469-488.

Roberts, Christopher. "ASEAN Institutionalisation: The Function of Political Values and State Capacity." RSIS Working Paper 217. S. Rajaratnam School of International Studies, Singapore, December 2010.

Severino, Rodolfo C. "ASEAN Beyond Forty: Towards Political and Economic Integration." Contemporary Southeast Asia 29, no. 3 (October 2007): 406423.

Shediac, Richard, Parag Khanna, Taufiq Rahim, and Hatem A. Samman. "Integrating, Not Integrated: A Scorecard of GCC Economic Integration.” Abu Dhabi: Booze and Company, 2011.

Shimizu, Kazushi. "The Asian Economic Crisis and Intra-ASEAN Economic Cooperation." Economic Journal of Hokkaido University 29 (2009): 67-83.

Sturm, Michael, and Nikolaus Siegfried. "Regional Monetary Integration in the Member States of the Gulf Cooperation Council." ECB Occasional Paper 31. Frankfurt: European Central Bank, 2005. 
Sturm, Michael,Jan Strasky, Petra Adolf, and Dominik Peschel. “The Gulf Cooperation Council Countries: Economic Structures, Recent Developments and Role in the Global Economy." ECB Occasional Paper 92. Frankfurt: European Central Bank, 2008.

Twinam, Joseph Wright. "Reflections on Gulf Cooperation, with Focus on Bahrain, Qatar and Oman." American-Arab Affairs 18 (Fall 1986): 14-35.

Ulrichsen, Kristian Coates. "The GCC States and the Shifting Balance of Global Power." CIRS Occasional Paper 6. Doha: Center for International and Regional Studies, Georgetown University School of Foreign Service in Qatar, 2010.

___ "Rebalancing Global Governance: Gulf States'Perspectives on the Governance of Globalisation." Global Policy 2, no. 1 (January 2011): 65-74.

“The Unified Economic Agreement." American-Arab Affairs 7 (Winter 1983-84): 177184.

Wahby, Mohammad. "The Arab Cooperation Council and the Arab Political Order." American Arab Affairs 28 (1989): 60-67.

Woertz, Eckart. “To Peg or Not to Peg.” Dubai: Gulf Research Center, 2007.

Yoshimatsu, Hidetaka. "Political Leadership, Informality, and Regional Integration in East Asia: The Evolution of ASEAN Plus Three.” European Journal of East Asian Studies 4, no. 2 (September 2005): 205-232.

- . "Collective Action Problems and Regional Integration in ASEAN." Contemporary Southeast Asia 28, no. 1 (April 2006): 115-140.

—_. "Regional Cooperation in Northeast Asia: Searching for the Mode of Governance." International Relations of the Asia-Pacific 10, no. 2 (May 2010): 247-274.

Zaidi, Iqbal. "Monetary Coordination among the Gulf Cooperation Council Countries." World Development 18, no. 5 (May 1990): 759-768. 


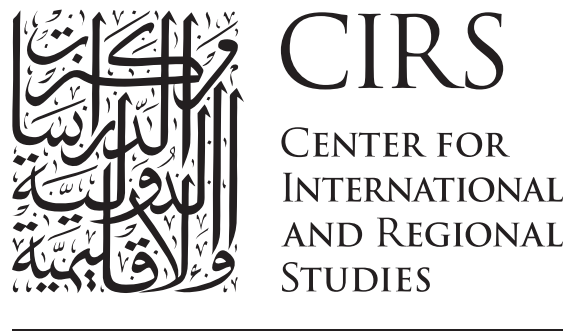

GEORGETOWN UNIVERSITY SCHOOL OF FOREIGN SERVICE IN QATAR

Center for International and Regional Studies Georgetown University School of Foreign Service in Qatar P.O. Box 23689

Doha, Qatar

http://cirs.georgetown.edu

$\mathrm{Tel}+97444578400$

Fax +974 44578401 


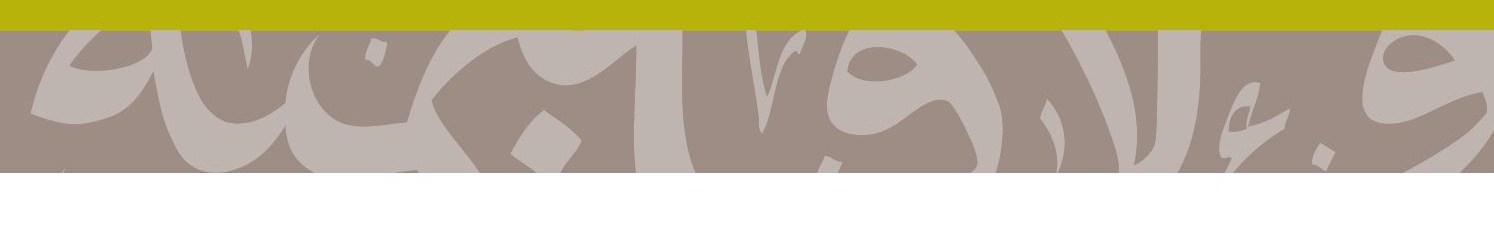

